\title{
Crimes without criminals
}

\section{Opinion}

There are crimes without victims and crimes without criminals. Financial crime belongs to the second type, as responsibilities for crises, crashes, bubbles, misconduct, or even fraud, are difficult to establish. The historical process that led to the disappearance of offenders from the financial sphere is fascinating.

In the Christian consciousness love for money was seen as a repugnant signal of greed and an obstacle to salvation: "No one can serve two masters: you cannot serve both God and Money". This biblical precept, however, was accompanied by the ambiguous command: "Render unto Caesar the things which are Caesar's, and unto God the things that are God's". St Francis was well aware of the threat hidden behind this dictum, as Christians might interpret it as a justification to establish the separate kingdom of Mammon. Usurers, however, were deemed "financial sinners", offenders whose earnings relied upon the exploitation of time, their finances being valorized through deferral. This was a sacrilege: time belongs to God. Eventually usury ${ }^{1}$ was able to move freely in the Christian conscience when, as historian ${ }^{2}$ suggests, the invention of Purgatory made it a venial and redeemable sin.

There were no sinners or criminals behind the financial bubble caused by the Dutch "tulip mania" in the late 1630s, when a bulb of the magnificent semper augustus reached the value of a Rembrandt's painting. Nor was any form of criminal activity detected in similar crises occurring in Paris and London, where at most the culprits were identified as gullible investors who thought they could amass wealth overnight. Whether buying flowers or stocks, investors were the victims of ineluctable natural causes, calamities that they attracted onto themselves through their own idiocy and, as Jeremy Bentham explained, no legislation can be designed to protect idiots.

Later we keep encountering crises, not sins, let alone crimes. The UK Bubble Act 1720 attempted to regulate financial practices and prevent manias. But after it was repealed in 1825, railways, robber barons, and crooks became the protagonists of the century. The collapse of the Royal British Bank and the Tipperary Bank occurred while, across the ocean, the careers of legendary tycoons such as Jay Gould, Cornelius Vanderbilt and John D. Rockefeller were in full swing. Smaller operators or petty embezzlers were targeted, while leading businessmen were condoned. Those described as villains managed to establish a reputation as generous philanthropists, and as the wealthy Christians of the past atoned through monetary donations, the new rich set up charitable organizations. The blame for financial criminality shifted more decisively towards its victims, namely imprudent and insatiable investors who engaged in what were blatantly fraudulent initiatives.

Blaming the victims continued for decades, leading some commentators to equate financial crime to rape, and Positivist criminologists to coin the term "criminaloid". How many "criminaloids" were responsible for the crisis of 1929 is hard to tell. When Wall Street collapsed it became clear that innovative financial strategies had mingled with unlawful schemes, creating openings for adventurers and swindlers. In criminology the concept of 'whitecollar crime' was forged, and offenders of high social status and
Volume I Issue I - 2017

\author{
Vincenzo Ruggiero \\ Professor of Sociology, Middlesex University, London
}

Correspondence: Vincenzo Ruggiero, Professor of Sociology and Criminology, Middlesex University, London,

Email V.Ruggiero@mdx.ac.uk

Received: August 21, 2017 | Published: September 06, 2017

respectability were finally included among its objects of study. John Maynard Keynes, ${ }^{3}$ who lost a remarkable portion of his investments during the crisis, described it as one of the greatest economic catastrophes of modern history, a colossal muddle showing how easy it is to lose control of "a delicate machine, the working of which we do not understand".

The Marshal Plan activated after WW2 helped rebuilding the economy in some European countries, but simultaneously gave rise to illicit appropriation of large sums and the creation of slush funds financing political parties loyal to the USA.

The names of Drexel, Milken, Maxwell, and Leeson marked the 1980s and 1990s, when the prosecution of some conspicuous villains did not alter the perception that criminal imputations in the financial sphere are inappropriate. This sphere, it was intimated, contains its own regulatory mechanism allowing for the harmless co-existence of self-interested actors. WorldCom, Enron, Parmalat and Madoff belong to the current century, which reveals how regulatory mechanisms are sidelined by networks of greed involving bankers, politicians, and auditors.

The 2008 crisis, finally, proves how specific measures aimed at avoiding future crises are criticized or rejected in the name of market freedom. Commenting on the crisis, Andrew Haldane, an Executive Director of the Bank of England, inadvertently reiterated Keynes' notion that knowledge of the financial world is poor and that not criminals but individuals immersed in uncertainty populate it: mistakes are made, but they are "honest', not fraudulent mistakes, and anyone could make them given how uncertain that world is.

When the Panama Papers were released, rather than uncertainty, one certainty came to light: crimes without criminals occur in grey areas where tax evasion, bribes, money laundering, and all other forms of "dirty money" constitute the hidden wealth of nations.

\section{Acknowledgements}

None.

\section{Conflict of interest}

The author declares no conflict of interest.

\section{References}

1. Bentham J. Defence of Usury. 4th ed. Payne and Foss, London; 1787. 
2. Le Goff J. Le Moyen Age et l'argent. Essai d'anthropologie historique, Perrin, Parigi, India; 2010.
3. Keynes JM. Essays in Persuasion. Macmillan, London; 1972. 